\title{
SUCCESSFUL MANAGEMENT OF PREGNANCY IN A CASE OF PROTEIN S DEFICIENCY-A RARE CAUSE OF RECURRENT PREGNANCY LOSSES
}

\section{Obstetrics \& Gynaecology}

Niranjan Mayadeo

Professor, Department Of Obstetrics And Gynaecology, Kem Hospital, Parel, Mumbai, India.

Anusha V Devalla*

Junior Resident, Department Of Obstetrics And Gynaecology, Kem Hospital, Parel, Mumbai, India. * Corresponding Author

\section{ABSTRACT}

Protein $\mathrm{C}$ and $\mathrm{S}$ are important mediators in coagulation. Their deficiency poses a high susceptibility of thrombosis, fetal losses, recurrent abortion, pre-eclampsia, abruption, severe morbidity and mortality. Pre-eclampsia seen in these women usually presents at an early gestational age and usually with high severity. The incidence varies as per the ethnicity with higher prevalence in the west. In Asian countries, Factor V Leiden mutation is seen more commonly associated with thromboembolic disorders. Aspirin and Low molecular weight Heparin is the mainstay of treatment. We describe a rare case of Protein S deficiency (50\% activity) in pregnancy presented with previous recurrent pregnancy losses in a 32 year old woman.

\section{KEYWORDS}

Protein C, Protein S, Heparin, Pregnancy Outcome, Pre-Eclampsia

\section{INTRODUCTION}

Protein S, Protein C and Ant thrombin III are important regulators of coagulation. While deficiencies of these proteins have been linked to adverse pregnancy outcomes, testing for these deficiencies during pregnancy is limited by the use of non-pregnant reference ranges and a limited understanding of the changes that occur during pregnancy. Occurrence of thrombosis in pregnancy is multifactorial owing to the physiological hypercoagulable state, vascular changes leading to increased stasis and impact of both the inherited and the acquired thrombophilias. (1) They can substantially lead to adverse consequence like pre-eclampsia, abruption, recurrent pregnancy losses, fetal growth restriction and even mortality.

Deficiencies of the natural anticoagulant protein C, S and Ant thrombin occur much less than $1 \%$ to $2 \%$ of the population. (2) Concomitant diseases such as systemic lupus erythematous or sickle cell disease as well as other risk factors including obesity, decreased mobility, increased age, and smoking all increase the risk of thrombosis.(3)

We report successful fetomaternal outcome in a case of protein $\mathrm{S}$ deficiency with 30 weeks pregnancy managed with low dose aspirin and low molecular weight heparin with previous pregnancy losses.

\section{CASE REPORT}

We report a case of 32 year old, marital life of 7 years, sixth gravida, no living issue, spontaneous conception and a diagnosed case of Protein $\mathrm{S}$ deficiency. The Protein $\mathrm{C}$ concentration being 63\% (normal- 70 to $130 \%$ ) and Protein S concentration 50\% (normal- 55-123\%). She presented to OPD with a positive urinary pregnancy test at 2 months of gestation. Her past obstetric history included 4 spontaneous abortions (all at 2-3 months of gestation) within 2 years of marriage and 1 intrauterine death, a year later, at 28 weeks with history of severe preeclampsia and placental abruption in her previous pregnancy. Inherited thrombophilia was diagnosed after her $3^{\text {rd }}$ abortion during the evaluation of recurrent pregnancy losses. Lupus anti-coagulant (negative), Anti-Cardiolipin antibody $\mathrm{IgM} / \mathrm{IgG}$ (negative), Antinuclear antibodies (negative), Anti thrombin III (87\%) were all within normal limits.

The patient was started on prophylactic doses of Tablet Aspirin $(75 \mathrm{mg}$ ) and Injection Low Molecular Weight Heparin $0.6 \mathrm{ml}$ (Enoxaparin) once a day daily dosing as soon as the cardiac activity was demonstrated on obstetric ultrasound. The high risk involved in the current pregnancy was explained. Routine antenatal investigations were within normal limits including the Level I, II scans and ultrasound of kidneys. Home blood pressure monitoring was advised and regular haematological opinions were sought.

At 24 weeks of gestation, she presented with increasing pedal edema (pitting grade 3 ) and her blood pressure was recorded to be $150 / 100$ $\mathrm{mm}$ of $\mathrm{Hg}$ and urinary proteins were $2+$. The patient was admitted for further evaluation and management, when she was started on Labetalol $100 \mathrm{mg}$ BD which had to be increased to $200 \mathrm{mg}$ QID in a week's time with addition of Tab Nifedipine (sustained release) $20 \mathrm{mg}$ BD by the end of 26 weeks when the BP rose to 170/110.Fetal heart rate was 150 beats per minute. Respiratory and Cardiovascular system examination showed no abnormality. On admission, complete hemogram and renal function tests were normal while liver function tests revealed raised SGOT/SGPT (180/216) and 24 hour urinary proteins $2342 \mathrm{gm} /$ day with a worsening trend (SGOT/ SGPT- 430/560) noted over the next 2 weeks. Prothrombin time was 17 secs and international normalized ratio was 1.3 (control $13 \mathrm{secs}$ ). Urine culture sensitivity was sterile. Ultrasound for obstetric Doppler stated mild uteroplacental and mild fetoplacental insufficiency but a normal fetal cerebral blood flow. Two doses of injection Betamethasone cover with $12 \mathrm{mg}$ at 24 hours apart were given. Ophthalmology opinion was taken and papilledema ruled out. Bi weekly Non stress tests and Bi weekly fetal ultrasounds were performed which showed a rise in the S/D ratio in the umbilical artery. The Doppler findings deteriorated in the next two weeks where the findings were suggestive of severe fetoplacental insufficiency with brain sparing effect.

However, with the continuous rise in the blood pressure (160/110) despite the highest doses of the said anti-hypertensives and worsening liver function tests and pedal edema (urinary proteins $3+$ ) and incidence of premonitory symptoms at 30 weeks, the decision for induction of labour was taken explaining the risk of a premature birth (with consultation of neonatologist) and related risks of severe preeclampsia. Low molecular weight heparin was stopped owing to its long duration of action (in any event of emergency LSCS). On vaginal examination, the cervix was closed, posterior and uneffaced hence preinduction cervical ripening was done by dinoprostone gel twice at an interval of 6 hours. This was followed by Oxytocin administration with the fetal heart tracings monitored continuously by cardiotocography. Emergency lower segment caesarean section was done in view of nonprogresson of labour and she delivered a live female child of 1095 grams. The baby was shifted to neonatal intensive care unit under cPAP ventilation.

Post-operative period was uneventful. Blood pressure readings became normal by day 3 , subsequently not requiring any antihypertensive. Haematological opinion was taken and anticoagulants continued post-operatively (LMWH combined with warfarin). The patient recovered well and was discharged along with the baby by day 27 of surgery when the weight rose to $1.4 \mathrm{~kg}$. At 2 months follow up, both the patient and the baby were doing well and appropriate contraception and home blood pressure monitoring advised.

\section{DISCUSSION}

Recurrent pregnancy loss (RPL) bears adversely on a woman's mental and physical health. It affects $1-2 \%$ of women of reproductive age group if 3 or more first trimester pregnancy losses (less than 12 weeks) and $5 \%$ if 2 or more first trimester losses. (4)

Pre-eclampsia, stillbirth, placental insufficiency and the haemolysis, elevated liver enzymes, and low platelet count (HELLP) syndrome are 
obstetric complications that may occur in thrombotic events in pregnancy.(5)

Protein S deficiency is associated with a variable increased risk of thrombosis and is inherited independently in an autosomal dominant trait. The protein $\mathrm{S}$ gene is located on chromosome 3.4 and it has been observed that there are over 90 different mutations of protein $\mathrm{S}$ gene. Incidence of clinically symptomatic protein S deficiency is 1:20 000 (6) Protein $\mathrm{S}$ functions as a co factor to facilitate the action of activated Protein $\mathrm{C}$ in factors Va and VIIIa. Protein S deficiency is defined by its decreased APC-cofactor activity and has been associated with an increased lifetime risk of venous and possibly arterial thrombosis.

Protein S deficiency may be inherited or acquired. It has been found that homozygous protein $\mathrm{C}$ or $\mathrm{S}$ deficiency may lead to lethal syndrome in neonates called purpura fulminans.(7) Husband in our case was screened for the same and results were within normal limits.

Owing to the increased risk of antepartum and postpartum venous thromboembolism, these women should receive thromboprophylaxis during pregnancy and puerperium. Subcutaneous low molecular heparin or unfractionated heparin are the anticoagulants of choice as they do not cross the placenta, unlike warfarin, hence non teratogenic. The latter is ;however, preferred with a better safety profile.

Reginal anesthesia is avoided for at least 12 hours after the last dose of LMWH. (7) Hence, LMWH was stopped during the time of induction.

Shen MC et al quoted that the use of heparin has been found to have strikingly higher live birth rates and lower pregnancy complications.(8) This has been also emphasized that women with high-risk thrombophilia should be considered for antenatal thromboprophylaxis regardless of family history of VTE by Gerhardt et al.(9)

Whereas the pragmatic use of combined aspirin and low molecular weight heparin has been advocated rampantly as a prophylaxis in a patient with recurrent pregnancy losses in preventing further losses but as per a trial conducted by Clark $\mathrm{P}$ et al in Scottish Pregnancy Intervention they concluded that Heparin offers no extra benefit when compared to intensive fetal surveillance.(4) The use has been controversial for a long time and the decision for use should be made on the discretion of the treating physician with proper evaluation and consultation sought from Haematologists and Rheumatologists.

Thrombophilia screening is a must for patients with recurrent pregnancy losses (including previous neonatal deaths) and should be performed in all pregnant women with recurrent fetal deaths after the 20th week as a way to identify possible causal factors suitable for treatment. (10)

\section{REFERENCES}

1. Said J, Ignjatovic V, Monagle P, Walker S, Higgins J, Brennecke S. Altered reference ranges for protein $\mathrm{C}$ and protein $\mathrm{S}$ during early pregnancy: Implications for the diagnosis ranges for protein $\mathrm{C}$ and protein $\mathrm{S}$ during early pregnancy: Implications for the diagnosis
of protein $\mathrm{C}$ and protein $\mathrm{S}$ deficiency during pregnancy. Thromb Haemost. $2010 \mathrm{Feb}$ of protein C

2. Parand A, Zolghadri J, Nezam M, Afrasiabi A, Haghpanah S, Karimi M. Inherited Thrombophilia and Recurrent Pregnancy Loss. Iran Red Crescent Med J [Internet]. 2013 Dec [cited 2020 Oct 4];15(12). Available from: https://www.ncbi.nlm.nih.gov/ pmc/ articles/PMC3955508/

3. Battinelli EM, Marshall A, Connors JM. The Role of Thrombophilia in Pregnancy. Nutescu E, editor. Thrombosis. 2013 Dec 18;2013:516420.

4. Clark P, Walker ID, Langhorne P, Crichton L, Thomson A, Greaves M, et al. SPIN (Scottish Pregnancy Intervention) study: a multicenter, randomized controlled trial of low-molecular-weight heparin and low-dose aspirin in women with recurrent low-molecular-weight heparin and low-dose as
miscarriage. Blood. 2010 May 27;115(21):4162-7.

5. Khalafallah AA, Ibraheem A-RO, Teo QY, AlBarzan A-M, Parameswaran R, Hooper E, et al. Review of Management and Outcomes in Women with Thrombophilia Risk during Pregnancy at a Single Institution. ISRN Obstet Gynecol [Internet]. 2014 Feb 17 [cited 2020Oct4];2014.Available from: https://www.ncbi.nlm.nih.gov/pmc/articles/PMC3945432/

6. Chaudhari HK, Shah PK, Pai KR, D'Souza NB. Combined protein C and protein S deficiency with pregnancy. Int J Reprod Contracept Obstet Gynecol. 2017 Feb 23;5(7):2450-2.

7. Lalan DM, Jassawalla MJ, Bhalerao SA. Successful pregnancy outcome in a case of protein s deficiency. J Obstet Gynaecol India. 2012 Dec;62(Suppl 1):21-2.

8. Shen M-C, Wu W-J, Cheng P-J, Ma G-C, Li W-C, Liou J-D, et al. Low-molecularweight-heparin can benefit women with recurrent pregnancy loss and sole protein $\mathrm{S}$ deficiency: a historical control cohort study from Taiwan. Thromb J. 2016 Oct 28;14(1):44.

9. Gerhardt A, Scharf RE, Greer IA, Zotz RB. Hereditary risk factors for thrombophilia and probability of venous thromboembolism during pregnancy and the puerperium. Blood. 2016 10;128(19):2343-9.

10. Barros VIPVL de, Igai AMK, Andres M de P, Francisco RPV, Zugaib M. [Pregnancy outcome and thrombophilia of women with recurrent fetal death]. Rev Bras Ginecol E Obstet Rev Fed Bras Soc Ginecol E Obstet. 2014 Feb;36(2):50-5. 